Columbia Law School

Scholarship Archive

2014

\title{
Reaching Out for Green Policies: National Environmental Policies in the WTO Legal Order
}

Petros C. Mavroidis

Columbia Law School, petros.mavroidis@unine.ch

Follow this and additional works at: https://scholarship.law.columbia.edu/faculty_scholarship

Part of the Environmental Law Commons, International Trade Law Commons, and the Law and Economics Commons

\section{Recommended Citation}

Petros C. Mavroidis, Reaching Out for Green Policies: National Environmental Policies in the WTO Legal

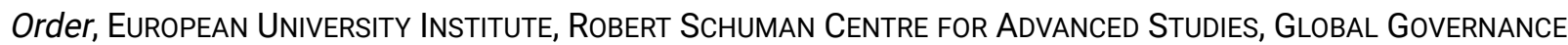
Programme Policy Paper No. RSCAS 2014/21; Columbia University SCHOOL OF LAW, THe Center for LaW \& ECONOMIC StUdies Working PAPER No. 474 (2014).

Available at: https://scholarship.law.columbia.edu/faculty_scholarship/2373

This Working Paper is brought to you for free and open access by the Faculty Publications at Scholarship Archive. It has been accepted for inclusion in Faculty Scholarship by an authorized administrator of Scholarship Archive. For more information, please contact scholarshiparchive@law.columbia.edu. 
The Center for Law and Economic Studies

Columbia University School of Law

435 West $116^{\text {th }}$ Street

New York, NY 10027-7201

(212) 854-3739

\title{
Reaching Out for Green Policies. National Environmental Policies in the WTO Legal Order
}

\author{
Petros C. Mavroidis \\ Columbia Law School
}

Working Paper No. 474

February 1, 2014

Do not quote or cite without author's permission.

An index to the working papers in the Columbia Law School Working Paper Series is located at

http://web.law.columbia.edu/law-economic-studies/working-papers 

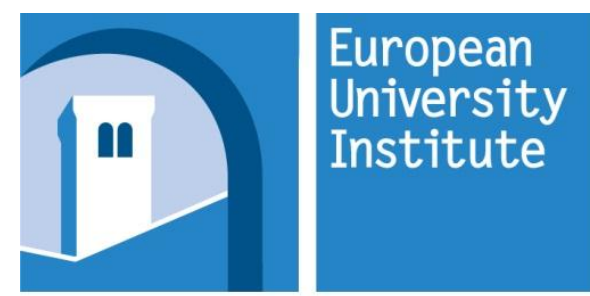

ROBERT

SCHUMAN

CENTRE FOR

ADVANCED

STUDIES

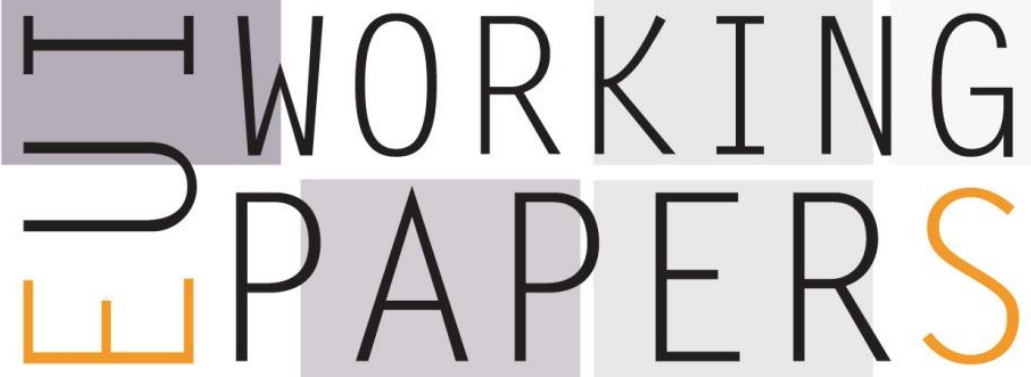

RSCAS 2014/21

Robert Schuman Centre for Advanced Studies Global Governance Programme-85

Reaching Out for Green Policies. National Environmental Policies in the WTO Legal Order

Petros C. Mavroidis 
European University Institute

Robert Schuman Centre for Advanced Studies

Global Governance Programme

Reaching Out for Green Policies. National Environmental Policies in the WTO Legal Order

Petros C. Mavroidis

EUI Working Paper RSCAS 2014/21 
This text may be downloaded only for personal research purposes. Additional reproduction for other purposes, whether in hard copies or electronically, requires the consent of the author(s), editor(s). If cited or quoted, reference should be made to the full name of the author(s), editor(s), the title, the working paper, or other series, the year and the publisher.

ISSN 1028-3625

(C) Petros C. Mavroidis, 2014

Printed in Italy, February 2014

European University Institute

Badia Fiesolana

I - 50014 San Domenico di Fiesole (FI)

Italy

www.eui.eu/RSCAS/Publications/

www.eui.eu

cadmus.eui.eu 


\section{Robert Schuman Centre for Advanced Studies}

The Robert Schuman Centre for Advanced Studies (RSCAS), created in 1992 and directed by Brigid Laffan since September 2013, aims to develop inter-disciplinary and comparative research and to promote work on the major issues facing the process of integration and European society.

The Centre is home to a large post-doctoral programme and hosts major research programmes and projects, and a range of working groups and ad hoc initiatives. The research agenda is organised around a set of core themes and is continuously evolving, reflecting the changing agenda of European integration and the expanding membership of the European Union.

Details of the research of the Centre can be found on:

http://www.eui.eu/RSCAS/Research/

Research publications take the form of Working Papers, Policy Papers, Distinguished Lectures and books. Most of these are also available on the RSCAS website:

http://www.eui.eu/RSCAS/Publications/

The EUI and the RSCAS are not responsible for the opinion expressed by the author(s).

\section{The Global Governance Programme at the EUI}

The Global Governance Programme (GGP) is research turned into action. It provides a European setting to conduct research at the highest level and promote synergies between the worlds of research and policy-making, to generate ideas and identify creative and innovative solutions to global challenges.

The GGP comprises three core dimensions: research, policy and training. Diverse global governance issues are investigated in research strands and projects coordinated by senior scholars, both from the EUI and from other internationally recognized top institutions. The policy dimension is developed throughout the programme, but is highlighted in the GGP High-Level Policy Seminars, which bring together policy-makers and academics at the highest level to discuss issues of current global importance.The Academy of Global Governance (AGG) is a unique executive training programme where theory and "real world" experience meet. Young executives, policy makers, diplomats, officials, private sector professionals and junior academics, have the opportunity to meet, share views and debate with leading academics, top-level officials, heads of international organisations and senior executives, on topical issues relating to governance.

For more information:

http://globalgovernanceprogramme.eui.eu 



\begin{abstract}
The WTO does not squarely address the issue of jurisdictional ambit of national policies (affecting trade). And yet, absent some agreement as to what trading nations can and cannot do, the WTO loses much of its effectiveness. In the absence of explicit regulation of the issue in the WTO contract, one would reasonably expect WTO Members to behave in line with the postulates governing allocation of jurisdiction embedded in public international law. WTO practice evidences neither an explicit acceptance nor a refusal of these rules.
\end{abstract}

\title{
Keywords
}

WTO; Environment; Jurisdiction

JEL Classification: K33 



\section{The Issue *}

WTO Members retain sovereignty over the design of domestic policies, as long as such instruments are not used for protectionist purposes: by 'domestic policies' we understand 'behind the border policies', e.g. policies that apply to both domestic as well as imported goods that have been cleared through customs; national health-, tax-, competition-, employment policies etc. come under the ambit of this term.

When regulating their own market however, nations often influence behaviour of third parties: a 'demanding' environmental policy will for example, keep the goods that do not meet the set standard away from the market. The WTO does not discuss jurisdictional rules at all, and is further silent on the nature of the relationship between WTO Law and the jurisdictional rules in public international law. Litigation before the WTO has shed little, if any, light on the role of the latter in the WTO-context. Without explicitly addressing the issue, GATT/WTO case-law has implicitly embraced the principle that WTO Members have the right to regulate the conditions under which they grant market access, irrespective of adverse effects for their trading partners.

The Appellate Body (AB), for example, held that the United States (US) could lawfully condition access of shrimps to its market on the prior satisfaction of a production process unilaterally decided by the US government, notwithstanding the fact that in order to export to the US market, foreign producers had to conform to a production process which they had not decided (indeed, which they could hardly influence, and which was contrary to that decided by their own government). They refrained however, from providing the rationale why the US has the right to do so.

The absence of comprehensive discussion on jurisdictional rules in the WTO-context is puzzling: jurisdictional rules are central to the effectiveness of any trade agreement. Consider a world consisting of two countries that can trade. Each government has access to one type of domestic policy instrument, taxes, and to one trade instrument, tariffs. ${ }^{1}$ Taxes can only be levied on economic activities, such as production, sales, and consumption of goods. Tax policies are perfectly enforceable, so any tax that is levied can also be collected without administrative costs, regardless of where the activity occurs. When setting its policies, each government is only concerned with the interests of its nationals.

Assume, first, that there are absolutely no jurisdictional restrictions on permissible policies. ${ }^{2}$ The exact tax/tariff schemes that the countries would choose in the absence of any form of policy coordination with other countries would depend on the details of the situation. But since governments have the possibility to tax any activity occurring in this hypothetical world, they would typically find it profitable to tax foreign as well as domestic activities. What is clear is that, since the governments often disregard foreign interests when deciding on their tax schemes, the possibility of taxing foreign activities would introduce beggar-thy-neighbour-like features in the tax schemes. An agreement binding border instruments would in all likelihood have no impact at all, absent jurisdictional rules: in this world, there would be no need to use trade instruments, since the possibility to tax foreign activities directly offers a more attractive means for beggar-thy-neighbour behaviour.

Suppose next that the agreement on tariffs is coupled with a National Treatment-like provision that restricts tax treatment of products in the domestic territory. It is hard, in general, to say whether such

For many helpful comments on previous drafts, I am indebted to Jagdish Bhagwati, Henrik Horn, Rob Howse, Mike Gerrard, Alan O. Sykes, and Mark Wu.

1 This example is from Horn and Mavroidis (2008).

2 Economics literature does not pay particular attention to the legal aspects of this issue, although it typically discusses the pros and cons of extra-territorial application of laws, compare for example, Nordahus (2013), Keith (2013), Hamilton (2013), and, for a more 'pragmatic' discussion, Sabin (2013). 
an agreement would have any impact at all. But the possibility would still remain to tax activities taking place in the foreign economy. As a result, very little, if anything, would be achieved through this agreement.

As a final case, suppose instead that the agreement on tariffs and quotas is coupled with a jurisdictional rule, prohibiting taxation of activities in the foreign country. In contrast to the previous two examples, this agreement is likely to have some impact. Note however, that the "trade part" of this agreement is immaterial, since the outcome is likely to be the same even if the bindings of the trade instruments were omitted. This will be the case, since, absent restrictions on domestic policies, the importing country can use production subsidies and consumption taxes to mimic trade barriers. ${ }^{3}$ In order to ensure that an agreed tariff reduction is meaningful, it must thus at the very least be accompanied by some form of restriction on the use of domestic policies.

The point we want to make through this abstract reasoning is that the trading rules must be supported by jurisdictional rules in order to have any impact. The trading nations were fully aware of this issue. They did not however, make references to public international law rules; instead, they tried to address the 'loophole' in the original contract through the Working Party on Border Tax Adjustments that we discuss in some detail in Section 2. Alas, their efforts were not crowned with success. We kick off this section with a brief explanation of the regulatory framework regarding the treatment of domestic policies in WTO. In this paper, we focus on the treatment of environmental policies, but the reasoning developed here should in principle, apply to any domestic policy affecting domestic goods as well as imports.

In the absence of legislative action, questions regarding the jurisdictional ambit of national measures were addressed in case law: Section 3 discusses in some detail the case law concerning the jurisdictional ambit of unilaterally defined environmental policies. Section 4 recaps the conclusions.

\section{The Discipline on Environmental Policies}

\subsection{The Law}

A central feature of the GATT ${ }^{4}$ is that it binds trade instruments: for instance, WTO Members have to respect the tariff concessions that they offered in the previous round; they are not allowed to use quantitative import or export restrictions; nor are they allowed to subsidize exports. The GATT leaves discretion, nonetheless, over internal (domestic) instruments to its WTO Members, although they are not entirely free to determine them to their liking: they must, in particular, respect the MFN provision (most favoured nation, Art. I GATT), and the NT provision (national treatment, Art. III GATT): Art. I GATT requests of each WTO Member not to treat the products originating in one WTO Member differently than the "like" products originating in any other WTO Member, both with respect to trade, as well as domestic instruments. Any trade advantage granted to the products of one WTO Member, must be accorded "immediately and unconditionally" to the "like" products originating in any other WTO Member. WTO Members must, by virtue of the legal discipline in Art. III GATT, avoid treating imported goods "so as to afford protection" to domestic "like" goods. Art. III GATT covers all fiscal instruments, as well as internal laws, regulations and requirements of non-fiscal nature that "affect" the life of imported products in a given market: a WTO Member can unilaterally define its environmental policy as it deems fit, but must apply it in non-discriminatory manner (over all imported and domestic "like goods). The GATT is, in this sense, a "negative integration" scheme,

3 For instance, a production subsidy (which is a negative tax) and a consumption tax of equal magnitude (levied on the domestic as well as the imported product) can do a perfect job of mimicking a tariff of this magnitude.

4 GATT stands for General Agreement on Tariffs and Trade, the agreement that regulates trade in goods, and comes under the ambit of the WTO. Grossman et al. (2013) discuss the basic features of non-discrimination in the GATT. 
since no common policies are established that all WTO Members should follow: the GATT states what is not allowed to be pursued (discrimination), rather than what should be done.

The GATT also contains in Art. XX GATT a loophole out of (at least formally) any other provision in the agreement, provided it is to achieve certain objectives included in this list. The list is exhaustive: WTO Members cannot, for example, through recourse to Art. XX GATT, address commercial externalities arising from low environmental standards in the exporting country, since such an objective does not figure in the body of Art. XX GATT. For a measure coming under the purview of this provision to be GATT-inconsistent, it must further not amount to "arbitrary or unjustifiable discrimination and/or a disguised restriction of trade". Standing WTO case-law has made it clear that the WTO judge will review only the means used and not the ends pursued (provided of course, that the ends pursued figure in the list of Art. XX GATT). ${ }^{5}$ The test for legal consistency differs depending on the objective sought. The measure has to be "necessary" in order to achieve some of the listed policy objectives, and it can simply "relate to" the protection of others.

Recall our discussion in the introductory remarks: absent some agreement on jurisdictional issues, the basic legal institutions of the WTO would become unmanageable. We turn to the discussion regarding jurisdiction in what immediately follows: recall that this issue has been addressed in public international law, but the WTO law (and case law) has not as yet explicitly endorsed it.

\subsection{Jurisdiction in Public International Law}

Bargaining solutions regarding allocation of jurisdiction can occur in domestic- as they can occur in international law. What we care about here though is the rules applicable when no bargaining solutions has been contracted in an agreement, let us call them the 'default rules' concerning allocation of jurisdiction. There are two, the territoriality- and the nationality-bases for prescriptive jurisdiction, and can be summarized as follows:

(a) The rules apply in situations where:

(i) we are neither in the realm of 'universal jurisdiction' (defined as cases where all nations have right to intervene, e.g. terrorism);

(ii) nor has a bargaining solution (international agreement) been negotiated;

(b) A state can lawfully exercise prescriptive jurisdiction ${ }^{6}$ :

(iii) on all activities occurring in its own territory (territoriality principle);

(iv) over its nationals, even for acts, omissions committed outside its territory (nationality principle).

In case of conflict between the two bases, the territoriality-principle prevails, a point to which we return in more detail infra (Section 2.3). ${ }^{7}$ In case an activity occurs in the territory of Home, but its

5 For confirmation, see the AB report on Brazil-Retreaded Tyres.

6 There are other bases as well which, exceptionally, might be relevant, such as the passive protective principle, whereby a state can claim jurisdiction on activities occurring outside its jurisdiction and aiming at one of its nationals. Anyway, this basis is of no interest to this paper. By the same token, there is widespread acknowledgement of the protective principle, which enables states to exercise jurisdiction against activity occurring outside its territory aiming at its national security, and there is special jurisdiction for activities occurring aboard vessels, aircrafts and spacecrafts: none of these two bases is of direct relevance to this paper.

7 Indeed, from early on it has been accepted that states cannot regulate in an extra-territorial manner. Viewed from this perspective the (ongoing) discussion on the nature of international law (whereby we distinguish between those that take the view that absent permissive international rules, no unilateral exercise of jurisdiction is permissible, and those who take the opposite view, that is, that international law can impose limits only to the exercise of unilateral jurisdiction) is futile. No matter what the starting point is, it will inevitably as the case, at least with respect to many transactions of 
'effects' are felt in the territory of Foreign, or in case the effects are spread over different states, all affected states are, in principle, competent to exercise (prescriptive) ${ }^{9}$ jurisdiction, and regulate the behaviour affecting them (effects doctrine).

\subsection{The Hierarchy between Territoriality and Nationality}

The hierarchy between territoriality and nationality is well documented. In its often discussed Lotus ${ }^{10}$ judgment, the Permanent Court of International Justice (PCIJ) said as much:

Now the first and foremost restriction imposed by international law upon a State is that -failing the existence of a permissive rule to the contrary- it may not exercise its power in any form in the territory of another State. In this sense jurisdiction is certainly territorial; it cannot be exercised by a State outside its territory except by virtue of a permissive rule derived from international custom or from a convention. ${ }^{11}$

The same principle has further been adopted early on by domestic courts. Justice Holmes, for example, proclaimed early in the 20th century:

... the general and almost universal rule is that the character of an act as lawful or unlawful must be determined wholly by the law of the country where the act is done. ${ }^{12}$

This does not mean that problems cannot arise in such a scenario: it could be, for example, that the punishment of an act by the state exercising jurisdiction invoking nationality is different from that of the state exercising jurisdiction on territoriality; in such cases, it could be that both states might wish to exercise jurisdiction in cumulative manner.

We can use the facts in Lotus as illustration: a Frenchman shoots from a French vessel (considered French territory) and kills a Turkish citizen on Turkish soil; the act takes place in France, its effects are felt in Turkey. The question arises who has jurisdiction in such cases? State practice first, and international courts later, have distinguished between objective and subjective territoriality: the former refers to jurisdiction for any act occurring within the national territory as circumscribed by the geographic frontiers, the effects of which are also felt within this territory; the latter covers cases where the effects of an act occurring outside the national geographic frontiers are felt within it (cases where there are, in other words, trans-boundary effects). In this latter case, jurisdiction to adjudicate the transaction is allocated to both Turkey and France.

\subsection{The Effects Doctrine (and its Discontents)}

Jurisdiction based on the effects doctrine is not uncontested. We read, for example, from the US Restatement on Foreign Relations Law ${ }^{13}$ :

(Contd.)

interest to this paper, that more than one jurisdictions will, in principle, legitimately believe that they can exercise jurisdiction. See on this point, Dunoff (2005), and Buxbaum (2006).

The interpretation of the term conflict is crucial here and there is asymmetric practice across states on this score: some will interpret it in a very strict manner and understand conflict a situation where the individual concerned cannot simultaneously comply with the legislation of two (or more) states. Others have adopted a looser standard: this is where the comity principle kicks in; some states will weigh their interest to regulate a particular transaction and will give in (to another state), if they judge that another state has more of an interest to regulate, even if the individual concerned could, in theory at least, comply with both regimes.

9 As opposed to enforcing their own rules which they might or might not be in position to do: e.g. what do against a foreign cartel that has no assets in the market where it practices supra-competitive prices?

10 France vs. Turkey, Judgment No 9, September 7, 1927, PCIJ Reports, 1928, Series A, No 10.

11 See Lotus, op. cit. at pp. 18-19. On this score, see also Parrish (2007), and Bradley and Goldsmith (2006) at pp. 625ff.

12 See Am. Banana Co vs. United Fruit Co. 213 US 347, 356-359 (1909). Recently, US courts refused to extend jurisdiction to foreigners challenging the consistency of actions by Swiss companies with US antitrust law, see F. Hoffman La Roche Ltd. vs. Empagran SA, 542 US 155, 164 (2004); see on this score, Klevorick and Sykes (2007). 
The effects principle is not controversial with respect to acts such as shooting or even sending libelous publications across a boundary. It is generally accepted with respect to liability for injury in the state from products made outside the state and introduced into its stream of commerce. Controversy has arisen as a result of economic regulation by the US and others, particularly through competition laws, on the basis of economic effect in their territory, when the conduct was lawful where carried out. This Restatement takes the position that a state may exercise jurisdiction based on effects in the state, when the effect or intended effect is substantial and the exercise of jurisdiction is reasonable under $\S 403$. (emphasis added).

A threshold issue is the magnitude of the effects that suffice for the effects doctrine to be applicable. The American Law Institute's prominent restatement of Foreign Relations Law of the United States (hereinafter the Restatement) takes the view that, at the very least, a jurisdiction must demonstrate substantial, direct, and foreseeable effects upon its territory. ${ }^{14}{ }^{15}$ Absent similar effects, countries cannot legitimately exercise jurisdiction.

What exactly substantial, direct, and foreseeable means is unclear. The most authoritative guide to their interpretation is state practice and international courts' decisions, as well as arbitral bodies' awards on this score.

State practice provides us, alas, with incoherent responses: there are states which liberally assert jurisdiction, and states which are more conservative in this respect. ${ }^{16}$ The lack of clarity in the default rules is exemplified, for example, in the divergent views of Kramer (1995) and Lowenfeld (1995) regarding the manner in which the US Supreme Court addressed the jurisdictional issue in the highly contentious Hartford Inc. case, which provoked the disapproval of the UK government that held the view that it alone had the right to prescribe jurisdiction over this particular transaction. State practice, nevertheless, is not always inconsistent: for example, at the time the Restatement was written, it is true that there was no unanimity across nations as to the application of the effects doctrine in antitrust issues.

The situation is different today with the application of the effects doctrine by the European Union (EU) and the US in several high-profile competition cases during the last two decades. ${ }^{17}$ Consensus has thus emerged regarding the acceptance of the application of the effects doctrine in a particular.

\subsection{Overlapping Jurisdictions}

It stems from the above, that it is quite possible that more than one state can exercise prescriptive jurisdiction by virtue of the territoriality principle. In this case, one can envisage several outcomes.

\subsubsection{Cumulative Application}

One possibility is the cumulative application of different legal regimes. There is strictly speaking nothing legally wrong with assigning jurisdiction concurrently to several sovereignties. ${ }^{18}$ For instance,

(Contd.)

13 See, The Restatement, op. cit.

See Restatement of the Law Third, Foreign Relations Law of the United States (1990) at p. 238. The Restatement is considered to be an authentic description of international law practice, and it is routinely cited in judgments of the highest courts around the world. It has thus exercised a de facto persuasive effect on courts in the United States and around the world.

15 See The Restatement op. cit. at pp. $244 \mathrm{ff}$.

16 For example, the United States has been often criticized for its policy in this respect both in the field of human rights, and in the field of international business transactions for asserting jurisdiction in too liberal a manner, see Lowenfeld (1995).

17 See the extensive analysis in Mavroidis and Neven (1999), and also Colangelo (2007).

18 This was largely the solution in the often discussed Lotus judgment by the PCIJ. (See France vs. Turkey, Judgment No 9, September 7, 1927, PCIJ Reports, 1928, Series A, No 10.) 
assume that stealing is punished with five years in prison in Home and seven years in Foreign. An individual who is convicted in both jurisdictions could spend two years in Foreign, having already spent five years in Home. However, it is easy to see that assigning jurisdiction to more than one state with divergent laws, has potentially serious drawbacks: the fact that courts or administrations in two or more countries will be involved in the decision making will lead to duplication of transaction costs; more importantly probably, the outcome of the combined regulation will typically not be optimal from any country's point of view. For instance, in the example above, Home might consider the additional two years of jail term excessive.

It could also be the case that the party involved cannot simultaneously comply with two decisions because they are contradictory. More generally, cumulative exercise of jurisdiction may mitigate as well as exacerbate problems stemming from unilateral decision making.

As a consequence of its many drawbacks, the assignment of overlapping jurisdiction is discouraged in many pronouncements by courts and international institutions. A prominent example is again the Restatement. Cumulative application of regulations nevertheless occurs quite often in practice.

\subsubsection{Comity}

A second possibility is that all but one state refrain from exercising jurisdiction, a solution that is often referred to as comity. This is most likely the case in situations where there is agreement that one state clearly has more of an interest to regulate a particular transaction or activity than other states which could have legitimately exercised prescriptive jurisdiction as well. For instance, the Restatement expresses support for this option (p. 247):

When possible, the two states should consult with each other. If one state has a clearly greater interest, the other should defer, by abandoning its regulation or interpreting it or modifying it so as to eliminate the conflict....

Since there is hierarchy between territoriality- and nationality-, reasonable exercise of prescriptive jurisdiction will be called for when the effects of an activity are 'felt' across various territories. The Restatement acknowledges as much:

Where regulation of transnational activity is based on its effects in the territory of the regulating state, the principle of reasonableness calls for limiting the exercise of jurisdiction so as to minimize conflict with the jurisdiction of other states, particularly with the state where the act takes place. (p. 250)

It is not easy to codify what should be considered reasonable exercise of prescriptive jurisdiction; it is, nonetheless, clear that this principle operates as a restraining factor (for some) on the exercise of jurisdiction. Under a 'reasonableness-standard', states will either through unilateral action (comity) or through a negotiated settlement conclude that some of them should not exercise jurisdiction over a particular transaction and let others do so.

In practice, one could imagine hundreds of scenarios where reasonable exercise of jurisdiction is called for. But rather than laying down general principles, the Restatement provides a comprehensive list of elements that constitute the reasonableness-standard. Consequently, a state, which, in principle, can legitimately exercise jurisdiction, might decide not to do so, based on a consideration which comprises, but is not necessarily limited to, the following criteria: ${ }^{19}$

(i) the link of the activity with another state (nationality, or territoriality, in the sense that there are direct, substantial and foreseeable effects with another jurisdiction);

(ii) the importance of regulating the activity to another state;

(iii) the existence of justified (legitimate) expectations;

19 See The Restatement, op. cit., at pp. 244ff. 
(iv) the importance of the regulation to the international system;

(v) the manner in which such transactions have been prescribed in prior relevant state practice.

The Restatement also provides an example of what could be considered unreasonable exercise of jurisdiction:

... regulation by the United States of the labor relations of a foreign vessel that regularly calls on the United States may be unreasonable; regulation of the vessel's safety standards may not be unreasonable. (p. 246)

The intuition here seems to be that, absent respect of strict safety standards on the foreign vessel, an accident might occur in US territory, or an environmental hazard that might have an impact (on US territory as well). The link with the US territory seems less strong in case, for example, workers on the foreign vessel receive wages below the statutory minimum reserved to the corresponding job when performed on US territory by workers legally employed in the US. ${ }^{20}$ As suggested above, a field (e.g., antitrust)-specific evaluation is warranted, since practice has developed in asymmetric manner across fields. $^{21}$

Comity happens quite rarely in practice however, because there is often disagreement as to which state should be the one designated to regulate. Take the example of an international merger between companies originating in Home and Foreign. Assume that $30 \%$ of their sales are in the market of Home, $25 \%$ in Foreign, 35\% in Third, and 10\% in Fourth. Should Third and Fourth desist simply because Home and Foreign companies are foreign? Or should Third exercise jurisdiction, being the country with the largest sales? And how should the antitrust authorities of Home and Foreign behave? Should both Home and Foreign regulate this transaction? Should one of them desist, and, if yes, on what grounds should it desist? What if the new merged entity will have a monopoly in Foreign, but no such thing in Home? Public international law sheds little, if any light, on this problem: there is no generally acceptable hierarchy across the various default rules, except for the one already mentioned, that is, that territoriality comes before nationality.

\subsubsection{Bargaining Solutions}

The third possible solution in case of overlapping jurisdictions is an international agreement. For instance, the Restatement points to this option:

...When neither state has a clearly strong interest, states often attempt to eliminate the conflict so as to reduce international friction and avoid putting those who are the object of the regulations in a difficult situation. (p. 247)

When two states search for a bargaining solution to address a jurisdictional ambiguity, they can allocate jurisdiction between them to their liking, to the extent that they do not interfere with the jurisdictional space of a third state.

As Parrish (2007, pp. 29ff.) points out, there has been an explosion of extra-territorial cases in copyright, securities regulation, trademarks and trade names, intellectual property, corporate law and

20 This is a very interesting example. We will come back to it when we discuss the applicability of our discussion here to environmental disputes.

21 One probable explanation is that, whereas there is an emerging world-wide consensus as to what should be the criteria for antitrust intervention, this is hardly the case in other fields of regulatory activity. Most competition regimes understand the role of antitrust as the means to promote rivalry in a given market, using consumer welfare as proxy to measure whether rivalry indeed exists. This quasi-uniformity concerning the substantive criteria for antitrust intervention probably explains the world-wide acceptance of the effects doctrine in this field: after all, the importing state is the one that suffers (in consumer welfare terms) from say monopolistic prices of a foreign cartel. 
governance, bankruptcy, tax, criminal laws, civil rights, labour laws - the list is endless. ${ }^{22}$ But the explosion of extra-territorial cases has not been accompanied by a clarification of the legal framework within which prescriptive jurisdiction should operate: the default rules continue to leave significant discretion to the state contemplating to exercise prescriptive jurisdiction, since we still lack rules as to which state should regulate when effects are spread over more than one territory. As a result, disputes across states as to who should be regulating a particular transaction are quite common.

\section{Into the WTO-Ring: Who Can Do What?}

\subsection{Commercial, Environmental Externalities}

As is often pointed out, the WTO Agreement is "incomplete" in the parlance of contract theory, in a number of ways. As a consequence of this incompleteness, the Agreement has been interpreted to include further restrictions than those explicitly stated in the text. A prime evidence of this feature is Art. XXIII.1 GATT, which specifies the legal grounds for a complaint. This provision states that

If any contracting party should consider that any benefit accruing to it directly or indirectly under this Agreement is being nullified or impaired as the result of

...the application by another contracting party of any measure, whether or not it conflicts with the provisions of this Agreement... (emphasis added)

As can be seen from the italicized terms, the Agreement involves commitments that go beyond what is explicitly stated in the text. This raises the question of what exactly is it that Members have agreed upon? This is an important question, since whatever Members have agreed upon, should fall outside the ambit of the default rules.

A first observation can here be drawn from the example we discussed in the Introduction: it is the default rules that prevent a country from imposing its tariffs or domestic instruments in foreign territory. For instance, the EU does not collect a value-added tax in the US market. If these rules did not exist it would be pointless to form the GATT. But the GATT and the default rules are in a sense not equally dependent on each other. While an imposition of the jurisdictional rules alone is likely to have some impact, in order for a GATT-like agreement to have any impact, it must be supported by jurisdictional rules. More importantly, for the GATT to be construed in accordance with its intended function as a negative integration agreement, it is quintessential that the default rules are observed.

One could here argue along two very different lines, leading to opposite conclusions concerning the applicability of the default rules. We believe both of these arguments are relevant, but that they are applicable to different situations.

One line of reasoning would focus on the fact that the agreement does regulate the pursuit of domestic policies through e.g. the non-discrimination provisions. Consequently, it could be argued, there is an implicit acceptance of whatever policies Members might choose that are consistent with this explicit regulation of domestic instruments. This view is reinforced by the fact that there are a couple of explicit remedies for unfair trade advantages, in the form of duties levied in the case of dumping and subsidization. According to this line of reasoning, since there is an implicit acceptance of the consequences of letting Members unilaterally decide on their domestic policies, the default rules are not applicable. There are some important shortcomings inherent in this view, and we will be returning to this point infra.

22 There is abundant literature on this issue. Vagts (2003), Avi-Yonah (2003), and Baumgartner (2004) provide a very adequate synthesis. 
A second line of reasoning instead starts from the observation that the WTO Agreement was not created in a legal vacuum, but in a situation where public international law, including the default rules, applied. Also, the Agreement does not contain any statement to the effect that these rules are not applicable. Hence, the only reasonable interpretation is that countries, when signing the Agreement, did so with the expectation that the default rules indeed are applicable.

In what follows we will argue that the first line of reasoning is applicable only in presence of what we call "commercial externalities", while the second argumentation is relevant in situations of "physical" (and possibly "moral") externalities. A (negative) commercial externality arises when lax environmental policies in the exporting country provides its exporters with a competitive advantage at the perceived expense of the importing country government. A "physical" trans-boundary externality from lax environmental policies takes the traditional form of, say, acid rain.

The fundamental reason why these two types of externalities, which stem from the exporting country's unilateral pursuit of environmental policies, are treated so differently, goes back to the basic purpose of the agreement. The GATT/WTO is an agreement regulating commercial relations between WTO Members. Hence, WTO Members should be assumed to have accepted the resulting commercial externalities from unilaterally pursued policies, to the extent these are not caught by the nondiscrimination provisions. As a result, the default rules do not apply in case of commercial externalities. In particular, the effects doctrine cannot be invoked to give a country the right to regulate against such an effect.

The WTO is not meant to regulate physical environmental externalities, however, and therefore it cannot be argued that WTO Members have agreed to accept trans-boundary physical externalities. Consequently, in the absence of other agreements - MEAs, for instance - the default rules are applicable.

More to the point: the very purpose of the GATT is to harmonize conditions of competition within and not across markets: once a ticket to entry, in the form of customs duty, has been paid, imported products should be treated as if they were domestic. Indeed, there would be no trade at all if the importing state could control for differences in income-taxation, EP-regulation and what have you. To paraphrase Dunoff, this would be the death of the trade regime, albeit for a different reason: prices of all goods would be equated to that of the highest de nominator. Trade is function of endowments and, in part, the outcome of competition across regulatory regimes as well. Societies make different choices as to the level of taxation, the level of EP, the level of antitrust enforcement etc. All such choices affect trade, even if only remotely so. By signing the GATT (and then the WTO), trading partners accepted to conduct trade on the basis of such differences. When they wanted to address some of them, they did so explicitly: the antidumping provisions are a very appropriate illustration here. This does not mean, nonetheless, that whenever there is silence, there is acceptance of the other's practices. This is precisely where the default rules kick in: Art. XX GATT explicitly allows WTO Members to deviate from their obligations in order to protect, inter alia, animal life. To do that, however, they must have jurisdiction over such animal life. Just like WTO Members cannot tax income of foreigners made abroad, they cannot, in principle, protect foreign animal life. To do that, they must show a nexus with their own jurisdiction (e.g., a change in the ecological equilibrium affects all nations). To accept the opposite would lead us to absurd results such as Home taxing Foreign nationals' income made in Foreign. In a nutshell, unless the default rules have been observed, the GATT cannot function, at the very least not in accordance with its intended function, that is, as an instrument promoting trade liberalization through negative integration.

\subsection{The Working Party on Border Tax Adjustments}

All this should be considered settled. Why however, did not the trading nations try to address jurisdictional issues when they realized how their actions could affect others? They did. Although not 
the central focus of the exercise, the Working Party (WP) on Border Tax Adjustments (BTA) did de facto address the issue of jurisdictional ambit. $\$ 4$ of the report defines 'border tax adjustments': ${ }^{23}$

... any fiscal measures which put into effect, in whole or in part, the destination principle (i.e. which enable exported products to be relieved of some or all of the tax charged in the exporting country in respect of similar domestic products sold to consumers on the home market and which enable imported products sold to consumers to be charged with some or all of the tax charged in the importing country in respect of similar domestic products. $)^{2425}$

The group was established following a request by the US: in the 1960s and 1970s, there was a lot of concern in the US about the impact of European indirect taxes, such as value added taxes (VAT) on international trade. European economies were becoming more competitive in this period. Actually, though, the US worries regarding taxation schemes adopted by European nations had already been expressed at earlier stage: Art. XVI GATT underwent a substantial revision during the GATT Review Session of 1955, when it was agreed that:

The exemption of an exported product from duties or taxes borne by the like product when destined for domestic consumption, or the remission of such duties or taxes in amounts not in excess of those which have accrued shall not be deemed to be a subsidy.

It was felt that this was an attempt to formally endorse the 'destination principle ${ }^{26}$ to indirect taxes: according to this principle, internationally traded commodities should be subjected to taxes of the importing country, and should be exempted from similar taxes imposed by the exporting country (in order to avoid double taxation). This principle contrasts with the 'origin principle', whereby it is the country where the good originates (as opposed to the country of destination) that retains the right to tax it.

The narrow question before the WP regarded thus, the GATT consistency of practices by the GATT contracting parties where the customs tariff was adjusted by the amount of an internal tax already imposed on domestic production; the wider issue was the perceived imbalance regarding the attitude of the GATT towards direct and indirect taxation.

The WP report reflects agreement on some measures, and disagreement on many others. The extent of the agreement is reflected in the following paragraph:

... the Working Party concluded that there was convergence of views to the effect that taxes directly levied on products were eligible for tax adjustment. Examples of such taxes comprised specific excise duties, sales taxes and cascade taxes and the tax on value added. It was agreed that the TVA, regardless of its technical construction (fractioned collection), was equivalent in this respect to a tax levied directly — a retail or sales tax. Furthermore, the Working Party concluded

23 GATT Doc. BISD 18S/97ff. This was the agreed definition at the time the report was being negotiated. Since, as we have argued in Horn and Mavroidis (2010), this report should be understood as a decision by the GATT CONTRACTING PARTIES, it is part of the GATT 1994, that is, an agreed definition.

24 The destination principle was taken over from bilateral agreements negotiated in the 1930s, such as the agreement of 6 May 1936 between the United States and France, see $\S 10$ of the Annex to the Working Party report on Border Tax Adjustments, op cit. See also Irwin et al. (2008).

25 Some discussion regarding precisely which taxes should come under the purview of Art. III GATT had already occurred even during the negotiation stage. At the Havana Conference, for example, the following view was reflected:

neither income taxes nor import duties fall within the scope of Art 18 (of the Havana Charter-Art III of the GATT) which is concerned solely with internal taxes on goods.

$\S 12$ of the annex to the Working Party report on Border Tax Adjustments, op cit. These were the words of the UK delegate, one of the key delegations in the drafting of Art. III GATT; see Irwin et al. (2008) and the corresponding discussion on 'property rights on the GATT'.

26 The destination principle was taken over from bilateral agreements negotiated in the 1930s, such as the agreement of 6 May 1936 between the US and France; see $\S 10$ of the Annex to the Working Party report on Border Tax Adjustments, op. cit. See also Irwin et al. (2008). Economists have used more or less the same definition for the term BTA. 
that there was convergence of views to the effect that certain taxes that were not directly levied on products were not eligible for tax adjustment. Examples of such taxes comprised social security charges whether on employers or employees and payroll taxes. ${ }^{27}$

Security charges, as well as payroll taxes escape thus the purview of Art. III GATT, in the sense that the importing state (Foreign) could not say raise the level of payroll taxes applied by the exporter (Home) to its own; by the same token Home (in case its payroll taxes were lower) cannot adjust them to the level of Foreign when exporting there.

There was divergence of views regarding the eligibility for adjustment of 'taxes occultes', and some other taxes, such as property taxes. The scarcity of complaints with respect to either of these two taxes, however, persuaded negotiators to stop negotiating them any further ( $\$ 15$ of the final report):

The Working Party noted that there was a divergence of views with regard to the eligibility for adjustment of certain categories of tax and that these could be subdivided into

(a) 'Taxes occultes' which the OECD defined as consumption taxes on capital equipment, auxiliary materials and services used in the transportation and production of other taxable goods. Taxes on advertising, energy, machinery and transport were among the more important taxes which might be involved. It appeared that adjustment was not normally made for taxes occultes except in countries having a cascade tax;

(b) Certain other taxes, such as property taxes, stamp duties and registration duties ... which are not generally considered eligible for tax adjustment. Most countries do not make adjustments for such taxes, but a few do as a few do for the payroll taxes and employers' social security charges referred to in the last sentence of paragraph 14.

It was generally felt that while this area of taxation was unclear, its importance-as indicated by the scarcity of complaints reported in connexion with adjustment of taxes occultes - was not such as to justify further examination.

Finally, there was agreement between negotiators that some taxes, such as 'cascade taxes' ${ }^{28}$ were eligible for adjustment, though the modalities for adjusting them were not clear ( $\$ 16$ of the final report):

The Working Party noted that there were some taxes which, while generally considered eligible for adjustment, presented a problem because of the difficulty in some cases of calculating exactly the amount of compensation. Examples of such difficulties were encountered in cascade taxes. For adjustment, countries operating cascade systems usually resorted to calculating average rates of rebate for categories of products rather than calculating the actual tax levied on a particular product. It was noted, however, that most cascade tax systems were to be replaced by TVA systems, and that therefore the area in which such problems occurred was diminishing. Other examples included composite goods which, on export, contained ingredients for which the Working Party agreed in principle it was administratively sensible and sufficiently accurate to rebate by average rates for a given class of goods.

The preceding analysis supports the conclusion that the WP on BTAs did not manage to resolve all ambiguities and disagreements regarding tax adjustability. Disagreements between trading partners regarding similar issues continued to persist and some of them found their way into GATT/WTO adjudication. Notoriously, the US subsequently enacted the DISC and FSC legislations, ${ }^{29}$ both of which were condemned, the first by a GATT Panel, the second by a WTO Panel and the AB. ${ }^{30}$

$27 \$ 14$ of the final report.

28 A cascade tax is a turnover tax which is applied at every stage of the production process.

29 The FSC dispute is discussed in Chapter 11. US-DISC, its GATT predecessor, was adjudicated during the GATT years. At stake was US tax legislation on Domestic International Sales Corporations. In brief, a US company that qualified as a DISC company would not be subjected to US federal income tax on its current or retained export earnings. Following a complaint, the Panel found that the US tax legislation constituted an export subsidy and was thus inconsistent with Art. 
Nevertheless, there was agreement in the WP concerning at least some of the taxes. The report of the WP on BTAs was adopted by the GATT CONTRACTING PARTIES, that is, the highest organ of the GATT. It is unclear whether it is a decision by the CONTRACTING PARTIES, and thus comes under the purview of Art. 1(b)(iv) GATT 1994, or whether it is part of the GATT acquis, and thus comes under the purview of Art. XVI of the Agreement Establishing the WTO. ${ }^{31}$ No matter how it is classified, the WP report will have legal significance: if it comes under the former it should be regarded as binding on all WTO Members, whereas if it comes under the latter it should be regarded as creating legitimate expectations that WTO practice will be guided by it. It seems that the better arguments lie with the view that the WP report should come under Art. 1(b)(iv) GATT 1994. After all, the WP was not convened to adjudicate a dispute between two GATT contracting parties; it was requested to discuss the treatment of tax adjustments in general.

In subsequent practice, a number of WTO Panel and $\mathrm{AB}$ reports have referred to this report, without however classifying it either as part and parcel of Art. 1(b)(iv) GATT 1994 or under Art. XVI WTO Agreement. ${ }^{32}$ But even if one takes the view that it should be considered to be part of the GATT acquis, it would still retain legal value, as explained above. The fact that it has been often cited in WTO case law leaves little room for doubt that recourse to it will be made again if, for example, the question of whether payroll taxes can be adjusted comes up. ${ }^{33}$

\subsection{Jurisdictional Issues in GATT Case Law}

\subsubsection{US-Canadian Tuna}

This dispute, which is the closest we have gotten to discuss jurisdictional issues in the GATT/WTO dispute settlement practice, has been surprisingly overlooked in literature. The facts are as follows: Canadian authorities seized US vessels and arrested US fishermen who were fishing within the 200 miles of the Canadian coast. ${ }^{34}$ In response, the US government, as per Section 205 of the US Fishery Conservation \& Management Act (1976), blocked all imports of Canadian albacore tuna into its market. Canada and the US consulted, without success and Canada submitted their dispute to a panel. Subsequently, they reached an agreement whereby the US government agreed to lift the embargo. The Canadian government, nonetheless, did not wish to suspend the panel's proceedings: in its view, the very existence of Section 205 constituted enough of a threat that similar behaviour could be repeated in the future; it thus requested the Panel to continue its proceedings and judge whether the US measure based on Section 205 was not GATT-inconsistent. ${ }^{35}$

(Contd.) XVI GATT. See GATT Doc. BISD 23S/98, and 28S/114. See also the very thorough analysis of the case by Jackson (1978).

30 On the overall stance of adjudicating bodies with respect to BTAs, see Bhagwati and Mavroidis (2007) and Demaret and Stewardson (1994).

31 For a detailed discussion of this issue, see Mavroidis (2008).

32 See, for example, the Panel and AB report on Japan-Alcoholic Beverages II.

33 Grossman (1980) examined to what extent indirect taxes, like the VAT, were origin neutral. He asserted the trade neutrality of uniform indirect taxes under both the origin and destination principles, and re-examined its validity in the context of a world with trade in intermediate goods. He showed that a uniform general sales tax is trade-neutral under the destination principle, but trade-distorting under the origin principle; a 'stage of processing' value added tax is nondistorting under either border tax adjustment principle.

34 According to customary international law, codified in the Convention on the Law of the Sea (UNCLOS III), the 200 miles-zone signals the exclusive economic zone that foreign countries cannot exploit without the consent of the coastal state having right to it.

35

The Panel should have adjudicated this as an as such claim, that is, as a claim against the US statute itself, and not against the measure that it gave rise to, since the measure ceased to exist before the Panel was established. 
The Canadian claim was that the US measure violated, inter alia, Art. XI GATT. The US government sought to justify its measure by invoking Art. XX(g) GATT, arguing that its measures sought to conserve an exhaustible natural resource. Canada did not dispute that tuna was an exhaustible natural resource, but argued that the US measures at hand had not been aiming at conserving tuna; they were rather meant to be a response to the seizure of US fishing boats by Canadian authorities, since the US government and another (un-named) state were the only two states which did not recognize the 200 miles Exclusive Economic Zone (EEZ) that every other nation member of the UN-system recognized as conferring exclusive economic rights to the coastal state.

On paper, it seems that this panel would unavoidably have been led to address the jurisdictional issue, that is, whether the GATT allows a country to regulate a common resource outside its border. Yet it declined to do so. It found the US measure to be in violation of Art. XX(g) GATT, since the US government had taken no accompanying measures aiming at restricting the fishing of albacore tuna by US fishermen. The Panel emphasized that its findings were meant to address the trade issue only, and that they should not be understood as an attempt to discuss the fisheries issue (which also involve a jurisdictional issue) as well:

Finally, the Panel would stress that its findings and conclusions were relevant only for the trade aspects of the matter under dispute and were not intended to have any bearing whatsoever on other aspects including those concerning questions of fishery jurisdiction. (§ 4.16)

\subsubsection{US-Tuna (Mexico)}

In this case, the US banned imports of tuna originating in Mexico, because its production process did not conform to the US process: by not using special (purse seine) nets, Mexican fishermen were accidentally taking the life of, for US standards, an unacceptably large number of dolphins.

The jurisdictional issue here could be described as follows: through its regulation of the conditions of sale for tuna to its own market, the US government imposed a production process requirement not only on domestic fishermen, but also on Mexican fishermen. The US was hence de facto regulating a production process that Mexican fishermen had to comply with, if they wanted to export to the US market.

Mexico did not attack the right of the US government to regulate this transaction. It challenged the consistency of the US measure with Art. XI GATT, since the US imposed an import ban. The US government did not present any arguments to rebut the claim that Art. XI GATT had been violated; instead, it sought justification of its measures under Art. XX(b) GATT, which allows WTO Members to justify violations of the GATT, if they can demonstrate that their measure is necessary to protect human, animal, plant life or health.

The Panel did not put into question the need, as perceived by the US government, to regulate the fishing of tuna in order to save dolphins' life. The Panel rejected, nonetheless, the particular way in which the fishing regulation was done: in the Panel's view, the US government had no basis to act unilaterally in this context. In the Panel's thinking, were WTO Members to be allowed to act unilaterally, the result would be a world where a plethora of national regulations would make it quite onerous to trade. Hence, in this Panel's view, any unilaterally defined EP is GATT-inconsistent, precisely because it has been unilaterally (as opposed to multilaterally) defined.

\subsubsection{US-Tuna (EEC)}

The facts of this case are strikingly similar to those in US - Tuna (Mexico). The only difference was that in this case, the US measure was applied to intermediary nations that were importing only to reexport tuna fished in an environmentally-unfriendly manner. The European Community (EC) and the Netherlands (on behalf of the Netherlands Antilles) challenged the consistency of the US measure and prevailed on the same grounds as Mexico did in the case mentioned immediately supra. 


\subsection{WTO Case Law}

We will distinguish between cases which directly disputes over the use of EP, and cases which concern disputes over the use of domestic instruments other than EP; since, however, all domestic instruments (environmental included) come under the same legal discipline (Art. III GATT), the WTO jurisprudence under this provision is at least potentially relevant for environmental disputes. Four cases come under the former class: US - Gasoline, US - Shrimp, EC-Approval and Marketing of Biotech Products, and Brazil-Re-treaded Tyres.

\subsubsection{US-Gasoline}

This case concerned a US measure which provided for different methodologies to be applied to domestic and foreign products in order to calculate the composition and emission effects of gasoline products sold in the US market. The US alleged that the rationale for the law was the protection of environment. The Panel and the AB first determined that EP come under the ambit of Art. III GATT (more recently, the panel report on EC-Approval and Marketing of Biotech Products confirmed this view.) They then found the measure to be inconsistent with the GATT because of its discriminatory aspect (different methodologies), and that it could not be justified through recourse to Art. XX GATT: in the AB's view, the measure at hand amounted to a disguised restriction of trade. The AB also held that the US failed to consider the costs for the complainants to comply with the regulation, and that it should have sought a bargaining solution, instead of unilaterally imposing its policies in this context.

The jurisdictional issue could be described as follows: the US maintained that it had the right to regulate the conditions under which gasoline products would be sold within its territory, since, environmental externalities in the production of gasoline products abroad could affect its territory as well, assuming the said externalities were of trans-boundary nature. The US thus exercised its prescriptive jurisdiction to this effect. The complainants argued that the US legislation was discriminatory in that it was introducing two different baselines to calculate the pollution created by activities undertaken domestically, and in the foreign territory. The complainants prevailed under Art. III GATT. Neither the Panel nor the AB addressed the jurisdictional issue at all. The AB, nonetheless, emphasized the relevance of PIL for adjudication in the WTO.

\subsubsection{US-Shrimp}

The facts in this case are strikingly similar to those in US - Tuna (Mexico); the difference is that the products concerned were shrimps and sea turtles, instead of tuna and dolphins. ${ }^{36}$ The US government adopted a statute whereby, sales of shrimps in the US market were conditioned upon the prior demonstration that a particular production process had been followed, which restricted the number of sea turtles that were accidentally being caught. ${ }^{37}$

The jurisdictional issue is the same as in US - Tuna (Mexico): the US government was regulating access to its territory (market) only, but imposed obligations on two sets of nationals, domestic and foreign, effectively regulating a production process that foreigners had to observe, assuming interest to export to the US market.

36 See Howse and Neven (2007) for an economic-cum-legal of core features of this dispute, and Howse and Regan (2000), and Howse (2002), for discussion of e.g. jurisdictional aspects.

37 The US fishermen were using turtle excluding devices (TEDs), a rather cheap device that allows sea turtles to swim out, in case they are caught. Initially, the US government requested that all foreign traders wishing to sell to the US market should demonstrate that their traded shrimps were fished using TEDs. Following multilateral rulings to this effect, the US government then accepted that not only TEDs, but any device of comparable efficiency, could be legitimately employed. 
The Panel and the $\mathrm{AB}$ reached opposite conclusions on the substance of the dispute. We will reflect only the latter, since the $\mathrm{AB}$ has the legal power to overturn panels' findings. ${ }^{38}$ The $\mathrm{AB}$ decision is a sea change when viewed against the background of the panel report on US - Tuna (Mexico): in an oftquoted passage, reproduced hereinafter, the $\mathrm{AB}$ held that the US government had the right to unilaterally define its environmental policy, provided that it observed the statutory requirements reflected in the GATT (in this occasion, the requirements embedded in Art. XX(g) GATT, that is, that the challenged measure was relating to the conservation of exhaustible natural resources, and was applied in a non-discriminatory manner). In other words, in the absence of transfer of sovereignty to the international plane, WTO Members remained free to unilaterally regulate their market, provided that they respect the relevant GATT disciplines $(\S 121)$ :

... conditioning access to a Member's domestic market on whether exporting Members comply with, or adopt, a policy or policies unilaterally prescribed by the importing Member may, to some degree, be a common aspect of measures falling within the scope of one or another of the exceptions (a) to (j) of Article XX. Paragraphs (a) to (j) comprise measures that are recognized as exceptions to substantive obligations established in the GATT 1994, because the domestic policies embodied in such measures have been recognized as important and legitimate in character. It is not necessary to assume that requiring from exporting countries compliance with, or adoption of, certain policies (although covered in principle by one or another of the exceptions) prescribed by the importing country, renders a measure a priori incapable of justification under Article XX. Such an interpretation renders most, if not all, of the specific exceptions of Article XX inutile, a result abhorrent to the principles of interpretation we are bound to apply. (italics and emphasis in the original).

This case-law has been consistently re-produced ever since. ${ }^{39}$ As a result, it is now uncontested, as a matter of jurisprudential finding, that Art. XX GATT condones regulatory diversity.

Having established the right of the US government to regulate this transaction in a unilateral manner, the $\mathrm{AB}$ went on to find that, while the US measure was necessary in the sense of Art. XX GATT, it was being applied in a discriminatory manner, and, thus, violated the chapeau of this provision. Following corrective measures, the US government was eventually exonerated from all liability under the multilateral rules.

Note that the $\mathrm{AB}$ did not pronounce, yet again, on the permissibility of the jurisdictional reach of the US measure: in the absence of a claim, the $\mathrm{AB}$ did not ex officio examine this issue either. The reason why this issue did not come up, was probably due to the fact that the measure was allegedly designed to protect sea turtles which migrate through US waters, so US territory was in this sense directly affected by the killing of the turtles. There was some discussion to this effect in the AB report, where the $\mathrm{AB}$ explained its view on the "sufficient nexus" between domestic and international environment. We quote $\S \S 133-134$ :

Finally, we observe that sea turtles are highly migratory animals, passing in and out of waters subject to the rights of jurisdiction of various coastal states and the high seas. In the Panel Report, the Panel said:

... Information brought to the attention of the Panel, including documented statements from the experts, tends to confirm the fact that sea turtles, in certain circumstances of their lives, migrate through the waters of several countries and the high sea. ...(footnote omitted by authors, emphasis added by $\mathrm{AB}$ )

The sea turtle species here at stake, i.e., covered by Section 609, are all known to occur in waters over which the United States exercises jurisdiction.(footnote omitted) Of course, it is not claimed that all populations of these species migrate to, or traverse, at one time or another, waters subject to United States jurisdiction. Neither the appellant nor any of the appellees claims any rights of

38 See Art. 17.13 of the Understanding on Rules and Procedures Governing the Settlement of Disputes (DSU).

39 See, for example, US - Shrimp (Art. 21.5-Malaysia) in $\S 137$ - 138. 
exclusive ownership over the sea turtles, at least not while they are swimming freely in their natural habitat -- the oceans. We do not pass upon the question of whether there is an implied jurisdictional limitation in Article $\mathrm{XX}(\mathrm{g})$, and if so, the nature or extent of that limitation. We note only that in the specific circumstances of the case before us, there is a sufficient nexus between the migratory and endangered marine populations involved and the United States for purposes of Article $\mathrm{XX}(\mathrm{g})$. (emphasis in original)

For all the foregoing reasons, we find that the sea turtles here involved constitute "exhaustible natural resources" for purposes of Article XX(g) of the GATT 1994..

Unfortunately, the $\mathrm{AB}$ did not elaborate any further and, consequently, the legal implications of this important passage are not entirely clear. One possible reading of this discussion, a reading that has been quite common in the literature, is that the $\mathrm{AB}$ here effectively held that the killing of sea turtles by e.g. Malaysian fishermen of shrimp physically affected the US environment, by reducing the turtle population in the US. However, while this is perhaps the most plausible reading, it should be noted that there is no explicit statement by the AB to this effect. Also, it is not clear whether the "nexus" is a necessary condition for Art. XX GATT to be applicable.

\subsubsection{EC-Approval and Marketing of Biotech Products}

Of interest to our paper are two issues treated by the panel: the fact that the Panel report confirmed that environmental policies come under the ambit of Art. III GATT, and the treatment of multilateral trade agreements (MEAs). With respect to the first question, the issue before the Panel was whether the EC-regime for approval of genetically modified organisms (GMOs) was consistent with a number of GATT and SPS provisions. The EC had argued that its system of approval was, inter alia, necessary to protect environment. The Panel agreed that similar policies come under the purview of Art. III GATT.

With respect to the second question, the EC had argued that its challenged measures were fully justified by the Cartagena Protocol on Bio-safety, an instrument which had been ratified by 142 states. The Panel took the view that since the instrument at hand had not been ratified by all WTO Members, it was legally irrelevant for the purposes of the litigation before it. In other words, the Panel did not exclude that an MEA might be legally relevant in future litigation; for this to be the case though, it must be ratified by all WTO Members.

This report was not appealed, so the $\mathrm{AB}$ had no opportunity to pronounce on this score. ${ }^{40}$

\subsubsection{Brazil-Re-treaded Tyres}

This is the most recent case dealing with EP. Brazil imposed an import embargo on re-treaded, but not on new tyres. The argument for the differential treatment was that re-treaded tyres have a shorter lifespan than new tyres and, consequently, represent more of an environmental concern. On the other hand, the embargo on re-treaded tyres was not non-discriminatory: Brazil did accept, however, some re-treaded tyres from its MERCOSUR partners, as well as from other trading partners, following some Brazilian court decisions to this effect.

The Panel condemned Brazil since its EP did not respect the chapeau of Art. XX GATT, holding that the Brazilian measure amounted to a disguised restriction of trade (and thus, violated the requirements of the chapeau of Art. XX GATT). The AB, while modifying some of the conclusions, essentially upheld this finding. But neither the Panel, nor the AB discussed the permissibility of the jurisdictional reach of the Brazilian EP. This is less of a concern compared to other cases however,

40 Mavroidis (2008) however, looking at the manner in which WTO adjudicating bodies have been looking on extra-WTO law, takes a pessimistic view on this score, arguing that the overall record of the AB shows a tendency to close the door to extra-WTO law rather than to open it. 
since the environmental externality that Brazil claimed to be regulating would be borne, in all likelihood, by Brazil alone.

\subsubsection{EC-Asbestos}

Based on scientific evidence, France enacted legislation banning sales of asbestos containingconstruction material into its market. Canada challenged the consistency of the measure with Art. III GATT; in its view, asbestos-containing and asbestos-free construction material should be awarded the same regulatory treatment since they are like products.

The Panel agreed with Canada that the contested measure violated Art. III GATT, but exonerated it under Art. XX GATT for being necessary to protect human life. The AB overturned the Panel's findings and held that France's measures were consistent with Art. III GATT: in its view, consumers would, if presented with a choice between the two types of products, not view them as like, due to the health hazard that the asbestos-containing product gave rise to. Since the two products were unlike, there could be no violation of Art. III GATT. ${ }^{41}$

The EC-Asbestos determination raises several difficult issues with regard to the role of consumer preferences for the definition of likeness. Without going into any detail, let us just point to a couple of these. A first issue is the notion of a "reasonable consumer", who is by construction a fictitious person who is endowed with what the AB sees as "reasonable" preferences. ${ }^{42}$ It goes without saying that the $\mathrm{AB}$ approach is a subjective exercise, in particular as long as the preferences of actual consumers are not investigated.

A second issue is the question concerning whether the perceived differences in products have to be reflected in the physical properties of the product. In this dispute, this was not an issue in the sense that the riskiness of the product was intimately associated with its physical properties. Some observers have interpreted the $E C$-Asbestos ruling to open the door to a wider interpretation whereby consumer preferences are decisive, regardless of whether the perceived differences are reflected in the physical properties of the product. $^{43}$

The $E C$-Asbestos determination also raises the question of whether consumer perceptions as such suffice as grounds for differential policy treatment? For instance, would products be unlike in a legal sense even if consumer perceptions are erroneous? As things stand, we do not know what the response to this question is. But our guess is that the $\mathrm{AB}$ would not lightheartedly accept consumer perceptions it believes are erroneous: in $E C$ - Asbestos the AB did not use surveys of EC consumer perceptions of the particular product; it adopted a "reasonable consumer" perspective, inferring how such a consumer would treat the two products. ${ }^{44}$

The jurisdictional issue in EC - Asbestos could be described as follows: France, by imposing the sales ban on asbestos containing construction material, regulates the effect of the consumption of such material in its domestic market. At the same time, it indirectly regulates the production in Canada, forcing Canadian producers to reduce or re-direct some of their production. To see that there is a jurisdictional issue involved here, note that France could have achieved the same (or at least a similar) outcome by regulating production in Canada rather than consumption in France. Since economically the outcomes are about the same, and the regulation of Canadian producers clearly involves a

41 See Horn and Weiler (2007) for a critical discussion, not of the outcome of the dispute, but of the adjudicating bodies' reasoning to get there.

42 In many civil law countries a similar construction exists.

43 It seems likely that consumer preferences are less decisive in cases adjudicated under the SPS Agreement.

44 It should be noted, nonetheless, that the $\mathrm{AB}$ did not have any empirical evidence before it. It should also be noted that it requested none. 
jurisdictional issue, so does implicitly also the regulation of consumption in France. Yet, once again, in the absence of specific claims to this effect, neither the Panel nor the AB explicitly addressed the jurisdictional issue.

\subsubsection{EC-Tariff Preferences}

The EC provided Pakistani textiles exports with preferences additional to those granted to Indian exporters under its Generalized System of Preferences (GSP). Overruling the Panel, the AB, found nothing wrong with the EC scheme, provided that it was relying on objective criteria. The term objective criteria was not defined by the $\mathrm{AB} .{ }^{45}$ To this effect, the EC had to effect modifications in its scheme which, when challenged by India, did not provide for access to any developing country which would satisfy its criteria, but granted extra preferences to a closed list of beneficiaries.

Of interest to this study is the fact that the EC scheme provided Pakistan with extra preferences by following a policy that the EC had determined; Pakistan did this by enacting decrees to combat the production and trafficking of drugs. By the same token, one could imagine that the EC could grant preferences, were Pakistan (or any other beneficiary) to adopt an EP to the liking of the EC. Although the term objective criteria was not defined by the $\mathrm{AB}$, it should cover situations which are not linked to one particular country; hence, the insistence of the $\mathrm{AB}$ that the $\mathrm{EC}$ removes the close list of beneficiaries.

The AB thus accepted that a WTO Member can provide preferences to another (developing) WTO Member, if the latter adopts policies that can rely on objective criteria, irrespective of the effect of such policies on the donor.

\section{Concluding Remarks}

The case law discussed above could be summarized as follows:

(a) Cases where a WTO Member aims at redressing a situation that will occur in its market if importation occurs (a local consumption hazard): EC-Asbestos, EC-Approval and Marketing of Biotech Products, Brazil - Retreaded Tyres;

(b) Cases where a WTO Member aims at redressing a situation that has occurred outside its territory, that is, in the territory of the exporting state, but which affects it (a trans-boundary production externality): US - Tuna (Mexico), US - Tuna (EEC), US - Canadian Tuna, US - Shrimp, US Gasoline;

(c) Cases where a WTO Member aims at redressing a situation that, prima facie at least, is not linked to either a production or a consumption externality: in this vein, a WTO Member aims at compensating those trading partners that adopt sound, in its view, policies by contributing (through preferential tariffs) to the costs that such policies might entail: EC-Tariff Preferences.

In neither of the cases presented above did the complainant raise any jurisdictional claims. In the absence of specific claims to this effect, panels did not address this issue either: at least implicitly, they accepted that when the WTO Member was regulating access to its market, it was lawfully exercising jurisdiction. The GATT panel on US - Canadian Tuna took a more cautious approach on this score and, as we saw supra, clarified that its findings were limited to the trade issue, and that it was not aiming to prejudge at all the fisheries (jurisdictional) issue.

The paucity of claims from disputing parties concerning jurisdiction naturally raises the question whether panels could not examine the jurisdictional reach of a WTO Member's measures ex officio, that is, even in the absence of a specific claim to this effect? This issue is, for all practical purposes,

45 Grossman and Sykes (2005) as well deplore that the AB did not interpret any further this term. 
water under the bridge. WTO panels, for a number of reasons linked to their half-legalistic, halfdiplomatic nature, are not keen in addressing issues that have not been explicitly referred to them.

Panels are further not likely to tinker with light-heartedly with domestic policies either, especially if they consider 'sensitive' issues, that is, important societal choices: ever since EC-Asbestos the AB has consistently held this line. This would lead us to take the view that, not only in cases where physical (environmental) externalities are at stake, but also when 'moral' externalities (e.g. disapproval by Home of Foreign's environmental attitude and corresponding action even if the environmental hazard is local in Foreign and not trans-boundary) have provided the basis for regulatory intervention, Panels might be willing to defer to non-discriminatory measures.

The absence of clarification regarding the legal relevance of the 'default rules' into the WTO legal order does not allow at this stage anything more than 'reasonable' speculation based on the overall attitude of Panels so far. 


\section{References}

Avi-Yonah, Ruben. 2003. National regulation of multinational enterprises: an essay on comity, extraterritoriality and harmonization, Columbia Journal of Transnational Law, 5, $17-57$.

Baumgartner, Samuel P. 2004. Is transnational litigation different? University of Pennsylvania Journal of International Economic Law, 25: 1297 - 1381.

Bhagwati, Jagdish and Petros C. Mavroidis. 2007. Is action against US exports for failure to sign the Kyoto-Protocol WTO legal? World Trade Review, 6: 299-310.

Bradley, Curtis and Jack Goldsmith. 2006. Foreign Relations Law: Cases and Materials, $2^{\text {nd }}$ edition, Aspen Press

Buxbaum, Hannah L. 2006. Transnational regulatory litigation, Virginia Journal of International Law, 46: $251-298$.

Colangelo, Anthony J. 2007. Constitutional limits on extraterritorial jurisdiction: terrorism and the intersection of national and international law, Harvard Journal of International Law, 48: 121 165.

Démaret, Paul and R. Stewardson. 1994. Border tax adjustments under GATT and EC law and general implications for environmental taxes, Journal of World Trade, 28: 5-65.

Dunoff, Jeffrey. 2005. Lotus Eaters: The Varietals Dispute, the SPS Agreement, and WTO Dispute Resolution, in George Bermann \& Petros C. Mavroidis, (eds). Trade and Health in the WTO, Cambridge University Press: Cambridge, Mass.

Grossman, Gene M., Henrik Horn, and Petros C. Mavroidis. 2013. Domestic Instruments, pp. 205345 in Henrik Horn and Petros C. Mavroidis (eds.), Legal and Economic Principles of World Trade Law, ALI, The American Law Institute Reporters' Studies on WTO Law, Cambridge University Press: New York City.

Grossman, Gene M., and Alan Sykes. 2005. A Preference for Development: the Law and Economics of GSP, World Trade Review 4: 41 - 68.

Hamilton, Clive. 2013. Earthmasters, Yale University Press: New Haven and London.

Horn, Henrik, and Petros C. Mavroidis. 2008. The Permissible Reach of National Environmental Policies, Journal of World Trade, 42: 1107-1178.

Horn, Henrik, and Petros C. Mavroidis. 2010. Climate Change and the WTO: Legal Issues Concerning Border Tax Adjustments, Japanese Yearbook of International Law, 53: 19-40.

Horn, Henrik and Joseph H.H. Weiler. 2007. EC - Asbestos, in Henrik Horn and Petros C. Mavroidis (eds), The American Law Institute Reporters' Studies on WTO Case-law - Legal and Economic Analysis, Cambridge University Press: Cambridge, UK.

Howse, Robert L. 2002. The Appellate Body's Rulings in the Shrimps/Turtles Case: a New Legal Baseline for the Trade and Environment Debate, Columbia Journal of Environmental Law 27: 491521.

Howse, Robert L. and Damien J. Neven. 2007. US - Shrimp, in Henrik Horn and Petros C. Mavroidis (eds.), The American Law Institute Reporters' Studies on WTO Case-law - Legal and Economic Analysis, Cambridge University Press: Cambridge, UK.

Howse, Robert L. and Donald Regan. 2000. The Product/process Distinction: an Illusory Basis for Disciplining "Unilateralism" in Trade Policy, European Journal of International Law 11: 249-283.

Irwin, Douglas A, Petros C. Mavroidis and Alan O. Sykes. 2008. The Genesis of the GATT, Cambridge Un. Press: Cambridge, Mass. 
Keith, David. 2013. A Case for Climate Engineering, MIT Press: Cambridge, Mass.

Klevorick Alan K. and Alan O. Sykes. 2007. United States Courts and the Optimal Deterrence of International Cartels: a Welfarist Perspective on Empagran, pp. 361 - 393 in Eleanor M. Fox \& Daniel A. Crane (eds.), Antitrust Stories, Foundation Press: New York.

Kramer, Larry. 1995. Extra-territorial Application of Antitrust law after the Insurance Antitrust Case: a Reply to Professors Lowenfeld and Trimble, American Journal of International Law, 89: $750-758$

Lowenfeld, Andreas F. 1995. Conflict, Balancing of Interests, and the Exercise of jurisdiction to prescribe: reflections on the Insurance Antitrust Case, American Journal of International Law, 89: $42-53$.

Mavroidis, Petros C. 2008. No Out-sourcing of Law? American Journal of International Law, forthcoming.

Mavroidis, Petros C., and Damien J. Neven. 1999. Application of Laws: a Law and Economics Analysis, pp. 1297-1325 in Mélanges Offerts à Michel Waelbroeck, PUB: Bruxelles.

Nordhaus, William. 2013. The Climate Casino, Yale University Press: New Haven and London.

Parrish, Austen L. 2007. Reclaiming International Law from Extraterritoriality. Mimeo.

Sabin, Paul. 2013. The Bet, Yale University Press: New Haven and London.

Vagts, Detlev. F. 2003. Extraterritoriality and the Corporate Governance Law, American Journal of International Law, 97: 289 - 299. 


\section{Author contacts:}

\section{Petros C. Mavroidis}

RSCAS, EUI,

Villa La Fonte

Via delle Fontanelle 10

50014 San Domenico di Fiesole (FI)

Italy

Email: petros.mavroidis@eui.eu 